\title{
Determinants of CEO Compensation Evidence from UK Public Limited Companies
}

\author{
Kibet K. Buigut ${ }^{1}$, Neddy C. Soi ${ }^{2} \&$ Irene J. Koskei ${ }^{2}$ \\ ${ }^{1}$ School of Business and Management Science, University of Eldoret, Eldoret, Kenya \\ ${ }^{2}$ School of Business and Economics, Moi University, Eldoret, Kenya \\ Correspondence: Kibet K. Buigut, School of Business and Management Science, Kenya. E-mail: \\ buigutt@gmail.com
}

Received: September 28, 2014

Accepted: November 24, 2014

Online Published: December 20, 2014

doi:10.5539/ijbm.v10n1p223

URL: http://dx.doi.org/10.5539/ijbm.v10n1p223

\begin{abstract}
In spite of more research on CEO compensation, where more of this research is anchored in agency or managerialist perspectives, less has been done on its determinants in firms. This paper contributes to the literature by determining the effect of Independent directors, CEO ownership and Profitability on executive cash compensation in UK. Agency theory informed the study. The study adopted an explanatory design Census technique was used as the study only included all the 20 firms for the past 3 years from 2008-2010. The study findings have shown that CEO ownership has a positive and significant effect on CEO compensation. The results have also show that the percentage of independent directors is significantly related to a decrease in the compensation levels of CEO compensation. Firm profitability was positively related to CEO compensation positing that CEOs salary as well as compensation increased with an increase in firm performance. It is therefore imperative for firms to link reward to corporate and individual performance so as to counter the agency problems. The interaction between corporate governance and CEO compensation is an avenue for more research for instance the relationship between shareholders and CEO compensation.
\end{abstract}

Keywords: CEO composition, CEO ownership, board independence, profitability

\section{Introduction}

In spite of a more research on CEO compensation, where more of this research is anchored in agency or managerialist perspectives, less has been done on its determinants in firms (Tosi, Werner, Katz \& Gomez-Mejia, 2000). CEO pay is the reward given to him/her which is a proxy of the salary. Recently, more research has been carried out. However, there has been a lot of controversy hence creating more and more the debate on CEO compensation. This has given studies on CEO compensation more attention. In the last century about 250 studies on chief executive officer compensation have been conducted, nevertheless the outcomes of these studies have been disappointing since mots of authors of these studies have been attempting to use many difference methods in measuring CEO compensations (Tosi, 1989, cited by Miller, 1995).

The compensation of (CEOs) is a matter of considerable interest to both academics and practitioners. More papers have determined factors that can affect the level of executive compensation (Cole \& Mehran 2008). CEOs are the most significant staff. They have the diverse ability todestroy or create or the value of the company (Ueng, 2000). To align the interests of the CEO with the company's interests, the most salient thing for a firm is to focus on the CEO's performance. For monitoring purposes, the Board of directors is responsible for overseeing the CEO because better control, such as smart governance and appropriate compensation of the CEO, can push the CEO to perform in the best interest of the shareholders and improve the performance of the firm (Boyd, 1994).

Prosperity of the firm depends upon the well-aligned interests of the CEO and the shareholders, and it is the responsibility of the board to align the CEO and shareholders to achieve the expected performance (Murphy, 1998). The Board of directors merges the interest of both parties through appropriate pay packages to the CEO (Bebchuk \& Fried, 2003). The decision about the CEO's compensation, which is the responsibility of the board of directors, can impact the performance of the firm in two ways. The first type of impact may be in the favor of the shareholder by generating more profit for the firm and secondly one of the most exasperating things to shareholders and the public is when a CEO receives millions or tens of millions of dollars of compensation 
regardless of performance (Murphy, 2002).

Despite the importance of this issue, there is only limited empirical evidence relating executive pay to the structure of the board. This paper contributes to the literature by examining the impact of the board structure on executive cash compensation in Kenya. It will be interesting to see whether and how the relationship between board structure and CEO compensation differs in the developing and emerging economy of UK, which has a different legal and institutional framework as compared to developing countries.

Studies have been giving complex results on determinants of CEO compensations throughout history due to CEO workplace diversity, heterogeneity in the firm, varying market demands, growth opportunities, varying board composition and the operations of firm have got complexity. As a result, the CEOs ability to sustain in this dynamic environment and the level of his compensations has gained extensive attention both in academic and non-academic concerns. Various studies have shown various determinants of CEO compensations such CEO ownership, firm size, profitability, market risk, power, CEO tenure among others. In addition, different measure of CEO compensations have been highlighted as cash compensation and bonuses paid to the CEO yearly. In this, study we use Independent directors, CEO ownership and Profitability as the CEO compensation determinates, while CEO cash compensation was used as measure of CEO compensation.

\section{Literature Review}

\subsection{Theoretical Framework}

Agency theory refers to the relationship between the shareholders and the company executives and the conflict that arises between the two. The reliance on the executives (the shareholders' agents) to manage the business can lead to it being managed in a way that may not always be in the best interest of the shareholders (McLaney, 2009). One of the solutions to the agency problems is to have a significant proportion of executives' remuneration structured so as to link reward to corporate and individual performance (Combined Code, 1998; Bander, 2005). According to Jensen and Murphy (1990) there are serious problem with CEO compensation as there is relentless focus on how much CEOs are paid which diverts the public from the real problem - how CEOs are paid. This results in executive compensation being independent of performance. In order to tackle the problem, Jensen and Murphy have drawn up three principles that will create the right monetary incentives for CEOs to maximise the value of their companies. First CEOs should own a substantial amount of company stock as this provides a powerful link between shareholders wealth and executive wealth. The problems with offering substantial ownership to CEOs is that giant companies such as IBM, General Motors or General Electric will never be able to grant CEOs a meaningful share of outstanding equity. Secondly, salaries, bonuses and stock options can be designed to provide big rewards for superior performance and big penalties for poor performance. In reality, cash compensation for CEOs is treated like an entitlement programme. More importantly, there are a small number of CEOs whose cash compensation changes in any meaningful way in response to corporate performance. Lastly, the threat of dismissal for poor performance can be made real. In a study of 2,505 executives, Jensen and Murphy found that on average CEOs hold their jobs for more than ten years before stepping down and most give up their title only after reaching normal retirement age

\subsection{Independent Directors and CEO Compensation}

The company board has the overall responsibility for determining the size and structure of salaries to the CEO. Some boards choose to assign this responsibility to the remuneration committee and remuneration committees usually consist of independent non-executive director. Perkins and Hendry (2005) listed factors that affect how CEOs are paid by studying the decision making process in executive remuneration and the role of the non-executive directors as intermediaries in the principle agency relationship. The specific conclusions Perkins and Hendry (2005) reached include the following. First, appointments and rewards of executives are made on specific circumstances that are a series of localized bargains and not determined by the market. Secondly, an attempt to resolve internal equity considerations and corporate governance transparency means that what matters is how rewards appear, not whether performance is objectively over-valued. Thirdly, the performance criteria adopted in agency theory discussions of top pay obscure wider social processes such as what society want from good governance and what shareholders truly value in executive performance. Lastly, board composition which is composed of a narrow population of non-executives has been criticized for being collusive, self-interested and self-perpetuating by virtue of a common background. That is to say that within the network of non-executive directors many are highly rewarded executive directors in their own companies which makes it difficult to operate unequivocally as representatives of the shareholder principal when it comes to compensating CEOs.

According to research of Kam Ming Wan boards with higher Percentage of independent directors don't have significant relation with CEO compensation level. (Wan). Opposite to results that we mostly have from 
developed countries about the insider director's effects upon the CEO compensation was found in India. Ramaswamy found that Percentage of insider directors don't have significant effect on CEO compensation in family-owned firms but in case of non-family organizations insider director can significantly affect the CEO compensation level (Ramaswamy, 2000).

Another study conducted by Neslihan Ozkan (2007) about corporate governance mechanism influence upon the level of CEO compensation. He used the data sample of 414 UK based firms for the year 2003 and 2004. The result shows that firms with larger board size and a higher Percentage of independent directors have positive and significant effect on CEO compensation level (Ozkan, 2007).

With reference to the study conducted by Nuno Fernandes (2008) about Portuguese Stock Market to examine the link between firm performance, board structure, and top executive pay. They conclude the same results as Nelihan Ozkan (2007) and they are doubtful about the effectiveness of independent board members. They found positive and significant association between the non-executive directors and CEO compensation level and an interesting finding is that if firm don't have the non-executive directors in board then firm faces the less problems and firm can converge the interest of shareholders and CEO in more better way (Fernandes, 2008).

A study conducted by Chhaochharia and Grin-stein (2009) about CEO Compensation and Board Structure in USA predicted that as Percentage of non-executive directors increases in cause a decrease in CEO pay (Chhaochharia \& Grinstein, 2009). Another study of Brian k. Boyd (1994) explains about the board control and CEO compensation. They used the data of 193 firms in across section of industries. They found that boards of directors are playing the key role in deciding about the CEO compensation. They arrived at the same result that CEO compensations is contrary to level of control (Boyd, 1994).

Paul Guest (2009) used the panel data analysis for 1,880 UK public firms over 1983-2002 to examine the effect of board structure on executive pay. They found that Percentage of non executive directors have significant negative relation with the level of executive pay whilst board size showed the positive significant relation with CEO compensation. Finally, when firms that increase the number of non-executives directors they examined that a decline in the rate of increase in executive pay (Guest, 2009).

A study about the Influence of Non-executive Director Control and Rewards on CEO Remuneration conducted by (Evans \& Evans). They investigate the relation between non- executive director control and remuneration effect on the CEO compensation decision. They found that the variable non-executive director control don't have a significant impact upon the determination of CEO pay levels. Secondly they found a significant relation between non-executive director's remuneration and CEO compensation and they found positive relation between these variables. It means that Non-executive director pay increases in line with CEO cash pay (Evans \& Evans).

Literature review explains the effect of board structure in different countries and settings e.g. UK, USA, Netherland, Hong Kong, Portugal and India and On the basis of literature review we can conclude that board structure can affect the CEO pay i.e. board structure have association with CEO pay because board is responsible to decide about the CEO compensation(Lehn, Patro, \& Zhao, 2003). But in case of executive directors, on-executive directors, in other words inside and outside directors have demonstrated mixed influence upon the CEO compensation. Some studies presents the positive and significant association of outside directors and some have negative association. Same with inside directors but some studies shows the insignificant relation between outside, inside directors and CEO compensation.

Overall literature review gives us the mixed results. So, on the basis of literature, review we cannot say what will be in our case. Another point to be noted that mostly these studies are in developed countries, only one case is from India that is developing and emerging economy but Indian corporate governance is almost like USA and UK. Board structure and CEO compensation relation in India are no quite different from USA and UK. Pakistan corporate governance system is also influenced by USA and UK so may be incase of Pakistan we will get the same results like India, USA or UK and may be due to majority of family firms in Pakistan we can get dissimilar results from the developed countries will help us to understand the relation between board structure and CEO compensation this will further help us to find the cause and effect relation between board and CEO compensation in Pakistan.

In the case of board composition, mostly researchers present a positive relationship between the percentage of non-executive directors on the board and the level of CEO compensation (Cyert, 2002, Ozkan, 2007) and a few of them are also proponents of no significant relationship (Core et al., 1999, Hallock, 1997).

\subsection{Profitability and CEO Compensation}

Profitability said to be major determinant of CEO compensation. Based on the literature firms should 
compesation their CEO on basis of how much they bring in the firm. Previous studies have used return on asset (ROA) and return on equity (ROE) as measures of firm profitability (firm Performance) (Finkelstein, Hambrick, 1989 \& Kubo, 2001). This study used ROA as it measure for profitability. According to previous studies (Finkelstein, Hambrick 1989; Deckop, 1988) profitability of the firms is a better determinants of CEO compensation. Firm profitability is positively related to executive compensation (salary). In their study, Jensen \& Murphy (1990) showed a weak relationship between CEO compensation and stockholders wealth. More Studies showed no relation between compensation and firm profitability (Fleming \& Stellios, 2002; Izan et al, 1998; Defina et al., 1994). Also, Tosi \& colleagues (2000) findings indicated weak relationship between CEO compensation and profitability. Similarly, Kubo (2001) shoed weak relation between CEO pays and company profitability in Japanese firms. Chalmers \& colleagues (2006) shows that Return on assets was positively associated with all compensation components except shares, only bonus component of executive compensation was associated with annual stock market returns, and CEO cash bonus was positively associated with both market and accounting returns.

\subsection{CEO Ownership and CEO Compensation}

Concerning CEO characteristics, age and tenure have a positive and significant influence on compensation. CEO ownership only influences significantly cash compensation. Hartzell and Starks (2003) provide empirical evidence for a strong positive relation between institutional ownership concentration and the pay-for-performance sensitivity of managerial compensation, as an evidence of the fact that large professional owner can be more sensible to the management incentive problem, and adopt more aggressive pay performance compensation. On a sample of Spanish firms, Crespi et al. (2002) show that the presence of a large shareholder is associated with a large sensitivity of cash based executive compensation to changes in shareholder value, while in firms with a less concentrated ownership, modifications in managerial compensation depend upon changes in accounting returns in prior years.

Further, Cyert et al. (2002) finds that larger CEO ownership results in higher pay levels in form of base salary, equity compensation or discretionary compensation. In a similar vein, Sapp (2007) finds that the CEO's total compensation decreases as the shareholdings of the CEO increase. However, Kahn et al (2005) finds that higher levels of CEO ownership lead to a significant reduction in the level of options compensation, as well as higher ratios of salary to total compensation and lower ratios of options to total compensation. As well, Core et al. (1999) states that CEO equity ownership significantly reduces the level of CEO compensation.

\section{Methodology}

The study adopted an explanatory design. This is because the research is a cause-effect relationship. Census technique was used as the study only included all the 20 firms for the past 3 years from 2008-2010. Data was collected from 60 financial reports of the sampled companies. The analysis of the data collected from financial statement followed a number of basic statistical techniques. Descriptive statistics (mean and standard deviation) and inferential statistics (Pearson correlation and multiple-regression) were used to analyze data. A multiple linear regression model was used to test the research hypotheses at 0.05 level of significance $(95 \%$ confidence level). The multiple regression model used in this study is given as;

$$
y_{i t}=\alpha_{i t}+\beta_{1} x_{1 i t}+\beta_{2} x_{2 i t}+\beta_{3} x_{3 i t}+\varepsilon_{i t}
$$

Where, $y=$ CEO compensation $\alpha=$ constant, $\beta_{1} \ldots \beta_{3}=$ the slope which represents the degree in which CEO compensation changes as the independent variable change by one unit variable. $x_{1}=$ Profitability, $x_{2}=$ Independent directors, $x_{3}=\mathrm{CEO}$ ownership, $\varepsilon=$ error term, $\mathrm{t}=$ measure of time, $\mathrm{i}=$ number of firm observation

\section{Results and Analysis}

Findings in table 4.1 showed that listed firms disclosed Return on Asset (ROA) at mean ratio of 6.1903. Further findings showed that $27 \%$ of the firms were locally owned (mean $=0.273903$ ) and the board had three independent directors (mean $=3.6)$.

Table 1. Descriptive statistics

\begin{tabular}{lllllll}
\hline & Min & Max & Mean & Std. Deviation & Skewness & Kurtosis \\
\hline Ownership & 0.0002 & 3 & 0.273903 & 0.568647 & 3.804 & 15.366 \\
Independent directors & 1 & 9 & 3.6 & 2.21091 & 1.171 & 0.365 \\
Profitability & -421.32 & 232.86 & 6.1903 & 95.55972 & -1.337 & 6.858 \\
\hline
\end{tabular}




\subsection{Correlation Results}

Pearson Product-Moment Correlation (r) was used to test the hypothesis. Pearson Correlations results in table 4.2 showed that ownership was positively and significantly correlated with CEO compensation $(r=0.725, \rho<0.01)$. Thus, ownership explains $72.5 \%\left(0.725^{2}\right)$ of the variation in CEO ownership. Profitability was also positively correlated with CEO ownership $(\mathrm{r}=0.354, \rho<0.01)$. As a result, profitability explained $35.4 \%\left(0.354^{2}\right)$ of the variation in CEO ownership. However, board independence was negatively associated with CEO ownership ( $\mathrm{r}=$ $-0.411, \rho<0.01)$ hence it contributes about $41.1 \%\left(0.411^{2}\right)$ of the variation in CEO ownership. Findings provided enough evidence to suggest that there was linear relationship between ownership, profitability and board independence with CEO ownership. Moreover, this provides enough ground support for multiple regression models to be performed.

Table 2. Correlation results

\begin{tabular}{lllll}
\hline & Compensation & Ownership & Board Independent & Profitability \\
\hline Compensation & 1 & & & \\
Ownership & $.725^{* *}$ & 1 & 1 & \\
Board independent & $-.411^{* *}$ & $-.301^{*}$ & -0.102 & 1 \\
Profitability & $.354^{* *}$ & 0.14 & \\
\hline
\end{tabular}

Note. $* *$ Correlation is significant at the 0.01 level (2-tailed).

* Correlation is significant at the 0.05 level (2-tailed).

\subsection{Model Summary}

The model summary indicates that $62.5 \%$ of the variation in the dependent variable is accounted for by the independent variables. This relationship is strong and significant, this is shown by the value of R-square $=0.625$. Further, there was no autocorrelation among the variable as indicated by Durbin Watson value $=1.556$ which was less than 2 thumb rule.

Table 3. Model summary

\begin{tabular}{lllll}
\hline R & R Square & Adjusted R Square & Std. Error of the Estimate & Durbin-Watson \\
\hline .791a & 0.625 & 0.605 & 67.03286 & 1.556 \\
& & \\
\hline
\end{tabular}

Note. b. Dependent Variable: compensation.

\subsection{ANOVA Model}

Table 4.4 shows that the regression model is significant $(F-v a l u e=31.127$ and $p$-value $=0.000<\alpha=0.05$ at 3 degrees of freedom).This implies that the joint prediction of profitability, board independence and ownership is significant. This shows that the model can be used in future to predict CEO compensation.

Table 4. ANOVA model

\begin{tabular}{llllll}
\hline & Sum of Squares & Df & Mean Square & F & Sig. \\
\hline Regression & 419595.2 & 3 & 139865.1 & 31.127 & .000 \\
Residual & 251630.7 & 56 & 4493.405 & & \\
Total & 671225.8 & 59 & & & \\
\hline Note. a Dependent Variable: CEO compensation; & & & \\
b Predictors: (Constant), profitability, board independence, ownership.
\end{tabular}

Hypothesis $1\left(\mathrm{H}_{01}\right)$ stated that ownership has no significant effect on CEO compensation. Findings showed that 
ownership had coefficients of estimate which was significant basing on $\beta_{1}=0.631$ (p-value $=0.000$ which is less than $\alpha=0.05$ ) thus we fail to accept the hypothesis and conclude that ownership has a significant effect on CEO compensation. This suggests that there is up to 0.631 unit increase in CEO compensation for each unit increase in ownership. Cognate to the results, Cyert et al. (2002) found out that higher CEO ownership results in higher base salary, equity compensation or discretionary compensation. However, Sapp (2007) is of a contrary opinion and finds that CEO's total compensation declines as the CEOs shareholding increases. Kahn et al (2005) is of a similar opinion and claims that CEO ownership results in a decline in CEOs compensation. Also, Core et al (1999) is also a proponent of the negative relation between CEO ownership and CEO compensation. From the foregoing, it is evident that most empirical studies show a negative relation between CEO ownership and CEO compensation (Kahn et al., 2005; Sapp, 2007; Core et al 1999).

Hypothesis $2\left(\mathrm{H}_{02}\right)$ revealed that board independence has no significant effect on CEO compensation. However, research findings showed that board independence had coefficients of estimate which was significant basing on $\beta_{2}=-0.196$ ( $p$-value $=0.026$ which is less than $\alpha=0.05$ ) implying that we reject the null hypothesis stating that board independence has no significant effect on CEO compensation. This indicates that for each unit increase in board independence, there is 0.196 units decrease in CEO compensation. Consistent with the results of the study, Chhaochharia and Grin-stein (2009) argue that as the percentage of independent directors' increases, CEO pay decreases. Also, Paul Guest, (2009) states that the percentage of nonexecutive directors have significant negative relation with the level of executive pay (Paul Guest, 2009). On the contrary, Ozkan, (2007) shows that there is a positive and significant effect between independent directors and CEO compensation. Similarly, prior studies that have focused on the board composition present a positive relationship between percentage of non-executive directors on the board and the level of CEO compensation (Main, 1991, Mangel and Singh, 1993, Cyert, 2002, Ozkan, 2007). Aside from the abovementioned empirical studies, research by Kam Ming Wan together with that of Ramaswamy, (2000) find no significant relation between independent directors and the CEO compensation level.

Hypothesis $3\left(\mathrm{H}_{03}\right)$ revealed that profitability has no significant effect on CEO compensation. However, research findings showed that profitability had coefficients of estimate which was significant basing on $\beta_{3}=0.246$ (p-value $=0.004$ which is less than $\alpha=0.05$ ) implying that we reject the null hypothesis stating that profitability has no significant effect on CEO compensation. This indicates that for each unit increase in profitability, there is 0.246 units increase in CEO compensation. In conformity with the results, Chalmers \& colleagues (2006) show that ROA was positively associated with all compensation components apart from bonus component of executive compensation and CEO cash bonus. In the same way, Finkelstein, Hambrick, (1989) and Deckop (1988) state that firm profitability is positively related to executive compensation.

To sum up, all the independent variables are statistically significant $(\mathrm{p}<0.05)$. The result also shows that predictor variables have positive coefficients apart from board independence. The VIF for all the estimated parameters was found to be less than 4 which indicate the absence of multi-Collinearity among the independent factors. As a result, the variation contributed by each of the independent factors was significant independently and all the factors should be included in the prediction model.

Table 5. Coefficient of estimate

\begin{tabular}{|c|c|c|c|c|c|c|c|}
\hline & \multicolumn{2}{|c|}{ Unstandardized Coefficients } & \multicolumn{3}{|c|}{ Standardized Coefficients } & \multicolumn{2}{|c|}{ Collinearity Statistics } \\
\hline & $\mathrm{B}$ & Std. Error & Beta & $\mathrm{T}$ & Sig. & Tolerance & VIF \\
\hline (Constant) & 107.327 & 18.889 & & 5.682 & 0.000 & & \\
\hline Ownership & 118.418 & 16.198 & 0.631 & 7.311 & 0.000 & 0.898 & 1.114 \\
\hline Board independent & -9.469 & 4.147 & -0.196 & -2.283 & 0.026 & 0.906 & 1.104 \\
\hline Profitability & 0.274 & 0.092 & 0.246 & 2.968 & 0.004 & 0.977 & 1.024 \\
\hline
\end{tabular}

Note. a Dependent Variable: CEO compensation.

\section{Conclusion}

The study findings have shown that CEO ownership has a positive and significant effect on CEO compensation. Particularly, larger CEO ownership results in higher pay levels, either base salary, equity compensation or discretionary compensation. The results have also show that the percentage of independent directors is 
significantly related to a decrease in the compensation levels of CEO compensation. Large independent directors do have an important monitoring role and appear to restrain the levels of CEO compensation. However, firms with limited number of independent directors are less effective resulting in higher CEO compensation. Furthermore, firm profitability was positively related to CEO compensation positing that CEOs salary as well as compensation increased with an increase in firm performance.

\section{Recommendation}

The study has delivered insights of the effect of ownership, independent directors and profitability on CEO compensation. As evidenced in the study results, CEO ownership has a positive effect on CEO compensation. As a result, firms need to set the compensation level of the CEO at a level that is justified and commensurate to firm performance. In a similar vein, profitability was shown to impact positively on CEO compensation. This is consistent with the agency theory. It is therefore imperative for firms to link reward to corporate and individual performance so as to counter the agency problems. Moreover, board independence had a negative effect on CEO compensation. As such, it is utmost necessary for firms to increase the proportion of independent directors on the board so as to impede CEOs from exerting power and influence over board directors by controlling factors such as their career opportunities. This way, the board will have the ability to effectively monitor the CEO and control CEO compensation since they will be subject to less CEO influence.

Further research on the determinants of CEO compensation should be primary aimed at collecting a larger sample size. This is possible by either increasing the number of firms or extending the sample period. Finally, the interaction between corporate governance and CEO compensation is an avenue for more research for instance the relationship between shareholders and CEO compensation.

\section{References}

Bander, R. (2005). Why do companies use performance-related pay for their executive directors? Corporate Governance, 12, 521-533. http://dx.doi.org/10.1111/j.1467-8683.2004.00391.x

Bebchuk, L. A., \& Jesse, M. F. (2003). Stealth Compensation. Mimeo, Harvard Law School and Boalt Hall School of Law.

Boyd, B. K. (1994). Board Control and CEO Compensation. Strategic Management Journal, 15(5), 335-344. http://dx.doi.org/10.1002/smj.4250150502

Chalmers, K., Koh, P. S., \& Stapledon. G. (2006). The determinants of CEO compensation. Rent extraction or labor demand? The British Accounting Review, 38, 259-275. http://dx.doi.org/10.1016/j.bar.2006.01.003

Chhaochharia, V., \& Yaniv, G. (2009). CEO compensation and board structure. Journal of Finance, 64, 231-261. http://dx.doi.org/10.1111/j.1540-6261.2008.01433.x

Cole, R. A., \& Mehran, H. (2008). What can we learn from privately held firms about executive compensation? Paper presented at the CES IFO Workshop on Executive Pay held in Venice, Italy July 16-17, 2008. Also presented at the Conference on Corporate Governance at Family/Unlisted Firms, Thun, Switzerland.

Combined Code. (1998, 2003, 2006). The Combined Code on Corporate Governance. London: Financial Reporting Council

Core, J. E., Holthausen, R. W., \& Larcker, D. F. (1999). Corporate governance, chief executive officer compensation, and firm performance. Journal of Financial Economics, 51(3), 371-406. http://dx.doi.org/10.1016/S0304-405X(98)00058-0

Crespi, R., Gispert, C., \& Renneboog, L. (2002). Cash-based executive compensation in Spain and UK. Corporate Governance Regimes: Convergence and Diversity.

Cyert, R. M., Kang, S. H., \& Kumar, P. (2002). Corporate Governance, takeovers, and top-management compensation: Theory and evidence. Management Science, 48(4), 453-469. http://dx.doi.org/10.1287/mnsc.48.4.453.205

Deckop. J. R. (1988). Determinants of Chief Executive Officer Compensation. Industrial and Labor Relations Review, 41, 215-226. http://dx.doi.org/10.2307/2523632

Defina, A., Harris, T. C., \& Ramsay, L. M. (1994). What is reasonable remuneration forcorporate officers? Company and Securities Law Journal, 12, 341-356.

Fernandes, N. (2008). EC: Board compensation and firm performance: The role of "independent" board members. Journal of Multinational Financial Management, 18(1), 30-44. http://dx.doi.org/10.1016/j.mulfin.2007.02.003 
Finkelstein, S., \& Hambrick, D. C. (1989). Chief executive compensation: A synthesis and reconciliation. Strategic Management Journal, 9(6), 543-558. http://dx.doi.org/10.1002/smj.4250090603

Fleming, G., \& Stellios, G. (2002). CEO compensation, managerial agency and boards of directors in Australia. Accounting Research Journal, 15(2), 126-145.

Guest, M. (2009). Board structure and executive pay: evidence from the UK. Cambridge Journal of Economics.

Hallock, K. F. (1997). Reciprocally interlocking boards of directors and executivecompensation. Journal of Financial and Quantitative Analysis, 32, 331-344. http://dx.doi.org/10.2307/2331203

Hartzell, J. C., \& Starks, L. T. (2003). Institutional investors and executive compensation. Journal of Finance, 58(6), 2351-2374. http://dx.doi.org/10.1046/j.1540-6261.2003.00608.x

Izan, H. Y., Sidhu, B., \& Taylor, S. (1998). Does CEO pay reflect performance? Some Australian evidence. Corporate Governance: an International Review, 6, 39-47. http://dx.doi.org/10.1111/1467-8683.00078

Jensen, M. C., \& Murphy, K. J. (1990). Performance pay and top management incentives. Journal of Political Economy, 98(2), 225-264. http://dx.doi.org/10.1086/261677

Khan, R., Dharwadkar, D., \& Brandes, P. (2005). Institutional ownership and CEO compensation: a longitudinal examination. Journal of Business Research, 58, 1078-1088. http://dx.doi.org/10.1016/j.jbusres.2004.02.002

Kubo. K. (2001-2). The Determinants of Executive Compensation in Japan and the UK: Agency Hypothesis or Joint Determination Hypothesis? CEI Working Paper Series, No. 2001-2 Institute of Economic Research Hitotsubashi University.

Lehn, K., Patro, S., \& Zhao, M. (2003). Determinants of the Size and Structure of Corporate Boards: 1935-2000. SSRN eLibrary. http://dx.doi.org/10.2139/ssrn.470675

Mangel, R., \& Singh, H. (1993). Ownership Structure, Board Relationships and CEOCompensation in Large US Corporations. Accounting and Business Research, 23(91), 339-350. http://dx.doi.org/10.1080/00014788.1993.9729902

McLaney, E. (2009). Business finance: theory and practice (8th ed.). Harlow: pearson Education.

Miller, D. J. (1995). CEO Salary Increases May Be Rational after All: Referents and Contracts in CEO Pay. The Academy of Management Journal, 38(5), 1361-1385. http://dx.doi.org/10.2307/256861

Ozkan, N. (2007). Do corporate governance mechanisms influence CEO compensation? Anempirical investigation of UK companies. Journal of Multinational Financial Management, 17(5), 349-364. http://dx.doi.org/10.1016/j.mulfin.2006.08.002

Perkins, S., \& Hendry, C. (2005). Ordering top pay: interpreting the signals. Journal of Management Studies, 42 , 1443-1468. http://dx.doi.org/10.1111/j.1467-6486.2005.00550.x

Ramaswamy. (2000). A study of the determinants of CEO compensation in India. MIR Management International Review, 40(2), 167.

Sapp, S. G. (2007). The Impact of Corporate Governance on Executive Compensation.

Tosi, H. L., \& Gomez-Mejia, L. R. (1989). The decoupling of CEO pay and performance: An agency perspective. Administrative Science Quarterly, 34(2), 169-189. http://dx.doi.org/10.2307/2989894

Tosi, H. L., Werner, S., Katz, J. P., \& Gomez-Mejia, L. R. (2000). How Much Does Performance Matter? A Meta-Analysis of CEO Pay Studies. Journal of Management, 26(2), 301-339. http://dx.doi.org/10.1177/014920630002600207

Ueng. (2000). CEO influences and executive compensation: large firms vs. small firms. Managerial Finance, 26(8), 3. http://dx.doi.org/10.1108/03074350010766800

\section{Copyrights}

Copyright for this article is retained by the author(s), with first publication rights granted to the journal.

This is an open-access article distributed under the terms and conditions of the Creative Commons Attribution license (http://creativecommons.org/licenses/by/3.0/). 